в Познани

mkuczynska55@gmail.com

\title{
Протестанты в царской России и их правовой статус
}

Abstract: Kuczyńska Marzanna, Protestanty v carskoj Rossii i ih pravovoj status (Protestants in the Tsarist Russia: Their Legal Status). "Poznańskie Studia Slawistyczne" 10. Poznań 2016. Publishing House of the Poznan Society for the Advancement of the Arts and Sciences, pp. 161-177 . ISSN 2084-3011.

The paper briefly presents the history of Protestantism in Russia $\left(16^{\text {th }}-19^{\text {th }}\right.$ century $)$ and the legal status of Protestant communities. An emphasis is placed on participation of the state and the individual tsars in increasing their number, as well as on the legal acts issued for them over the centuries. The article draws attention to the dependence of the right to freedom of religion, which they had in Russia, on their economic usefulness. It highlights the authorities' interference in the functioning of Protestant Church as well as state protection of the prevailing faith - the Orthodox Christianity - despite numerous religious and economic privileges granted to the Protestants.

KeYwords: Russia; Protestantism; Evangelical Lutheran Church; Baptism; legal status; religious privileges

Современная Россия довольно редко ассоциируется с каким-либо другим вероисповеданием чем православие, но православная Церковь отнудь не живет в религиозно однородном окружении, а протестантизм является одной из традиционных религий страны. Круг верующих формируют как иностранцы, так и местное население. История русского протестантизма многовековая, богатая и наряду с тем сложная. Религиозная политика государства во многом зависела от отношения монархов к вопросам конфессиональной свободы, их личной приверженности к православию и значимости Православной церкви в период их правления.

Исторически протестантские деноминации в России были представлены лютеранством, реформатскими общинами, хугенотством, англицизмом, меннонитством, баптизмом и др. Лютеране появились 
скоро после начала реформации (20-30-е гг. XVI в.) вследствие приглашения великим князем Василием III немецких, шведских, финских специалистов - ремесленников (оружейников, литейщиков пушек, мастеров горного дела), землепашцев, художников (ювелиров, денежных мастеров), торговцев, врачей. Василий также завел при себе почетную стражу из наемных иноземцев (литовцев, поляков, немцев), среди которых были и инославные. И при Иване Грозном приглашались мастера разных специальностей, переводчики, типографщики, хирурги, аптекари, но это ливонская война (1558-1583) послужила одним из факторов весьма увеличивших число лютеран. Первым приходом, официально открытым для них ${ }^{1}$, стала церковь (получившая со временем название св. Михаила) в Москве в Немецкой слободе 2 , построена в 1575 или 1576 г. (Курило 2002: 16; Fechner 1876: 90). В связи с дальнейшим расширением границ государства и вхождением в его состав народов, традиционно исповедующих протестантизм, количество протестантов постоянно росло. Особенно увеличилось в XVIII в. К концу XIX в. в России проживало более 7 млн. протестантов. До 60-х гг. XIX в. практически не было протестантов из славянских народов России, позже ситуация поменялась.

Начальная фаза развития протестантизма подробно освящена многими авторами (ср. Курило 2002: 14), хотя и не лишена некоторой мифолигизации. В большинстве работ она начинается с правления Ивана IV, в которых исследователи подчеркивают большой интерес царя к новому вероисповеданию, участие его в догматических диспутах ${ }^{3}$, обширную богословскую переписку и уважение к пасторам, которых царь считал „учеными и образованными” (Барсов 1993: 406; Одерборн 1585).

${ }^{1}$ Неизвестно по чьему ходатайству, определенное влияние на решение царя могли оказать члены английской торговой компании (Горсей 1991: 70; Цветаев 1883: 98).

${ }^{2}$ Слобода была организована, главным образом, для 4 тыс. военнопленных лифляндцев. „Немцами” в то время именовались любые иностранцы, не знавшие русского языка (,немые”).

${ }^{3}$ Самый известный диспут состоялся 10.05 .1570 г. с чехом Яном Рокитой, проживавшим в Польше, членом чешских братьев, который приехал в Россию с посольством польского короля для заключения перемирия между Россией и Польшей. Царь задал Яну несколько вопросов, потом отправил ему письменный ответ с опровержением догматов его веры (Марчалис 2009). 
По мнению других ученых, соблюдающих нейтралитет, а иногда враждебно относящихся к неправославным в России ${ }^{4}$ контакты с иноверными Грозного являлись необходимой частью государственной политики, строго отстаивавшей интерес отечества, защищавшей права и чистоту господствующей религии (Миненко 2011a). В действиях протестантов они усматривают подвох и попытки добиться своих целей хитростью (Цветаев 1890: 5; Ларионов 2006). Одновременно все согласны в том, что протестанты оказались в Москве в выгодном положении, получив вместе с экономическими и бытовыми льготами свободу вероисповедания (Цветаев 1883: 69; Курило 2002: 14).

Ряд привилегий не означает однако, что протестанты завоевали себе какое-либо особое место в стране. Их держали в изоляции от общества, запрещали религиозную пропаганду (включая колокола в храме), общение с русскими ${ }^{5}$, бракосочетание с православными (Цветаев 1883: 69; 1890: 5; Миненко 2011б). Догматический уровень протестантского учения ставился намного ниже католицизма (Цветаев 1890: 5), а лютеранская община стала по сути политическим заложником Ивана Грозного - в 1578 (или 1580) г. он отомстил „немцам” за переход ливонского короля Магнуса на сторону своего противника, Стефана Батория. Под предлогом спекуляцией протестантами водкой царь приказал разрушить их церковь, дома, а самих жильцов выгнать на улицу (Маржерет 1982: 156). Цветаев, один из первых исследователей истории русских протестантов, констатировал также факт, что Иван Грозный своей политикой создал модель отношений с инославными, применяемую, в большей или меньшей степени, всеми его преемниками.

Положение протестантов в московском государстве улучшилось в царствование Федора Иоанновича (1584-1598) и особенно Бориса Годунова (1598-1605), „покровителя иноземцев”, на поддержку

\footnotetext{
${ }^{4}$ Бескомпромиссный подход свойствен церковной научной среде и части „патриотически" идентифицирующихся публицистов.

5 Доказательством тому является ответ Ивана IV на просьбу папы не держать в стране лютеранских министров, только римских священников: „О люторех сказано, что в Российском государстве всяких вер люди многие живут, и своим обыкновением, а к Русским людем не пристают; а хотяб кто и похотел пристати, и тому того чинить не попускают" (Миллер 1788: 102).
} 
которых он рассчитывал в своей политике, не являясь наследственным правителем. Разрушенная немецкая слобода возвелась снова, организована была первая реформатская община и немецкая школа. Годунов предоставил иностранцам полные гражданские права, дал свободу проведения богослужений и право на построение церкви (Курило 2002: 20; Буссов 1998: 32). В каталоге-справочнике Москва евангельская авторы вспоминают также, что допускалась и протестантская пропаганда (2012: 9).

В XVII в. отношения государства к протестанским общинам обусловливались, с одной стороны, событиями смуты, вызвавшими недоверие к иностранцам, с другой, желанием Алексея Михайловича, второго Романова на царском престоле, создать русскую империю на основании собственной православной традиции, в центр которой ставились идеи преемства, единства, святости древней Руси (Послание изаря... 2005: 162). Церковь со своей стороны стремилась оказать влияние на протестантский вопрос, хотя и династия Романовых вела политику превосходства царства над священством.

Первый Романов симпатизировал протестантам. Предполагается, что имя лютеранской „кирхы”, св. Михаил, было формой признательности царю за его благоволение к инославным. Но даже царская милость не смогла сберечь их от церковной политики охраны православия. Из-за недовольствия священников, жаловавшихся на нарушения общественного порядка ${ }^{6}$, близость „кирх” к „церквям Божьим”, большую покупку земельных участков, в 1643 г. по царскому приказу протестантские храмы столицы были снесены (Указная книга... 1889: 163-165). В ущерб протестантам пришло также право Соборного уложения 1649 г., согласно которому иностранцам запрещалось покупать недвижимость в столице. Указами 1652 и 1654 гг. все иноверные, кто не принял православие, должны были переселиться из города в образованную за его пределами новую Немецкую слободу (см. Миненко 2008)7. Тем не менее

${ }^{6}$ Известен был скандал 1626 г., вызванный ссорой между женами военных и купцов, после которого община лютеранов разделилась на два прихода „купеческий” и „офицерский”. Последний построил себе храм в начале 1640-х гг. в центре Москвы (Олеарий 2003: 338-339).

${ }^{7}$ По свидетельству Олеария дело произошло не без участия Церкви. Началом послужило приключение патриарха во время крестного хода - он как всегда благословил 
власти не препятствовали чужим правительствам покровительствовать протестантам - итак, по ходатайству саксонского двора в 1662 г. в Москве образовалась новая лютеранская община, существовавшая за счет немцев. В конце своего царствования Алексей Михайлович не сопротивлялся обитанию знатных протестантов в центре Москвы и в других городах. Им также было дано право отправлять богослужения в своих жилищах и организовать молитвенные дома.

На кануне XVIII века в России развились уже протестантские Церковные институты. Однако, государственная власть не признавала их существование, учитывая иноверные общины как внерусское движение, держала их в ведении Посольского приказа.

C восшествием на престол Петра I началась одна из наиболее благоприятных эпох для неправославных ${ }^{8}$. По мнению многих, царь лично покровительствовал „немцам”, сам иногда посещал кирхи и исполнял духовные гимны. Приглашая манифестом от 1702 г. западнеевропейских специалистов, имел в виду интерес строившейся империи, военные планы и административно-общественные реформы. Приезжим гарантировал право свободного отправления религиозных ритуалов, строительство храмов, вступление в браки с русскими без перекрещивания в православие (ПС3, т. 6: 413-415)9. Не была позволена также публикация противопротестантских сочинений, как это случилось с известным Камнем веры митрополита Стефана Яворского.

В то же время началось существенное воздействие государства на институциональную жизнь протестантов - особенно после северной войны, когда Россия захватила значительное количество шведских земель (1721). С целью включения приходов в систему государственного управления, установливался контроль над их деятельностью ${ }^{10}$.

народ, но протестанты, одетые как и другие не оказали ему должного уважения. Никон рассердился и выхлопотал у царя поощрение права (Олеарий 2003: 338-339).

${ }^{8}$ В силу условий также для католиков, только евреи лишены были прав.

${ }^{9}$ Право охватывало только „ученых и мастеров разных специальностей”. Людям „в учении неискусным” бракосочетание с православными запрещалось из-за угрозы принятия супругом протестантства. Члены царской семьи и боярства без препятствий вступали в родство с немецкими дворянскими родами - за исключением до середины XIX в. царственных особ.

${ }^{10}$ Система прекратила функционирование только в 1917-1918 гг. 
Власти упорядочили протестанстскую религиозную организацию путем учреждения должности суперинтендента евангелических церквей ${ }^{11}$. Нормализировали юридический статус инославных, разработав Справной устав иерковной или евангелической лютерския веры (Ревель 1717 г.). В 1721 г. вопросы управления и надзора за протестантскими общинами из ведомства Коллегии иностранных дел ${ }^{12}$ были отданы Синоду православной Церкви (см. Ревуненкова 2007; Терюкова 2010).

Синод предписаниями к старшим пасторам округов (т. е. препозитам) регулировал церковную жизнь протестантов, требуя от них главным образом „несовращать” православных. Все иноверные духовные лица были обязаны явиться в Синод во время пребывания в столице. Контролировалась перемена места их жительства. За изборами пасторов следил особый препозит. Синод давал разрешение на постройку храмов, совершение служб. По его распоряжению в протестантский реестр дней молебствий, который считался государственным законом, вносились обязательные для всей Российской империи богослужения по случаю одержанных побед, восшествия на престол, поминовения государя и т. П. Пасторы и все иностранцы-протестанты, поступая на государственную службу, приносили присягу на верность императору, императрице и их детям. В целом, контроль за поведением протестантского духовенства воспринимается исследователями не таким бдительным, как за католиками (Ревуненкова 2007).

Практика веротерпимости Петра I не шла наперекор традиционной политике поддержки православного вероисповедания, реальной опоры светской власти среди простого народа. Кроме запрета распространять инославие, дети в смешанных семьях должны были быть крещены в православную веру; сохранила силу смертная казнь за уход из православия ${ }^{13}$. На территориях с доминирующим протестантизмом

${ }^{11}$ Стал им Бартольд Фагет (Фагеций), 1711-1718. „Патентом” от 7.10.1715 г. царь вверил Фагецию „крепкое” смотрение за верующими, в особенности пленными шведами, чтобы не причиняли ущерба государству, обращая таким образом пастора в государственного чиновника.

${ }^{12}$ Образованная в 1718 г. из Посольского приказа.

${ }^{13}$ Дела отступников рассматривали в церковных и гражданских судах; обычно их предавали анафеме, но постановлялись и смертные приговоры. 
государство по-прежнему одобряло миссионерскую деятельность православных. В присоединенных к московской Церкви (1686) епархиях западной и южной Руси, входящих в состав Речи Посполитой, где протестантизм имел долгую традицию совместного и тесного существования с другими конфессиями, Петр приказал ввести духовную цензуру над печатными литургическими книгами, чтобы охранять православное вероучение:

Великому Государю (...) извъстно учинилось, что въ Киевской и Черниговской типографияхъ, въ печатных книгах печатают несогласно с великороссийскими печатьми, которыя со многою противностию Восточной церкви, а именно въ Чернигове учебные часословы по желанию раскольническому, (...) въ книгъ Богомыслия, которая печатана в типографии Святотроицкой Ильинской въ 1710 году явилась многая люторская противность (...) дабы никакой розни и особаго нарђчия в оных не было (...). А других никаких книг (...) в тъхъ монастырях не печатать, дабы не могло в таких книгах никакой в церкви восточной и с Великороссийскою печатью несогласия произойти (ПС3, т. 6: 244-245).

Правление Анны Иоанновны (1730-1740), когда большое воздействие на внутренние дела империи начала оказывать т. н. „немецкая придворная группировка”, ознаменовалось ослаблением конфессиональной дисциплины. Императрицу обвиняли в гонениях на православие, на полемическую литературу ${ }^{14}$ и в покровительстве иноверным. По словам современников, повторяемых и сегодня, „немцы” даже добились значительных успехов в распространении религиозной пропаганды (Доброклонский 2001: 634).

Несомненно улучшилась в то время институциональная позиция неправославных Церквей. Управление ими (также римским католицизмом), как „иностранными” было передано из Синода новоучрежденному (23.02.1734) Консисториальному заседанию Юстиц-коллегии Лифляндских, Эстляндских и Финляндских дел (далее: ЮЛЭФ) с административно-судебными функциями. Год позже (18.02.1735) вышел манифест о свободе вероисповедания, без прав на распространение чужой веры (ПС3, т. 9: 482).

Дочь Петра I, Елизавета (1741-1761), которая вследствие дворцового переворота провозгласила себя новой императрицей и на

${ }^{14}$ Имеется в виду запрещенный цензурой Камень веры. 
которую полагались надежды на возвращение „древней русской благочести”, будто бы оскверненой либерализмом „немецкой партии”, хотя и облегчила долю православной церковной среды, отменив некоторые невыгодные для нее постановления предшественницы, но не стала вести категорически другую политику по отношению к протестантам. Двумя своими указами $O$ воспрещзении лютеранским пасторам крестить по своим обрядам детей православных родителей... и $О$ запрещении всем разных вероисповеданий иностранцам, (...) превращать в свой закон русских подданных... обновляла силу давних законов, служивших ограничением распространения инославия в пределах государства. Одновременно императрица подтверждала все гражданские и религиозные свободы жителям северной части России, захваченной у немцев и шведов в разные времена. С 1758 г. лютеране официально могли устраивать при кирхах кладбища.

Конфессиональная политика Екатерины II (1762-1796) во многом сравнивается с эпохой Петра I, который модернизировал страну, пользуясь опытом „немцев”. Царица в свою очередь осуществляла программу развития государства путем освоения призванными с Запада иностранцами пустующих на юге и востоке территорий ${ }^{15}$. Поскольку разосланный вскоре после восхождения ее на трон манифест (4.12.1762) с предложением иностранцам принять российское подданство и заселить пустующие земли не принес ожидаемого результата, 22 июля 1763 г. был издан манифест $O$ даруемых иностранным переселенциам авантажах и привилегиях, в котором гарантировались помощь в обустройстве на новом месте и ряд дополнительных привилегий, в том числе религиозных ${ }^{16}$. Поселение инославных в России,

${ }^{15}$ Мысль организовать земледельческие колонии принадлежала еще Елизавете Петровне. В историографии существует также тезис, что приглашение большого количества „немцев” Екатериной было одним из механизмов уравновешивания настроев общества, так как множество русского дворянства сопротивлялось ее правлению из-за незаконного присвоения власти.

${ }^{16}$ Напр., свободный выбор места для поселения, общинное самоуправление, освобождение от налогов (в необжитых землях на срок до 30, в обжитых - от 5 до 10 лет), от воинской службы, право в любое время покинуть Российскую империю (История российских...).

Предусмотрена была даже возможность получить индивидуальные, особые привилегии. 
особенно братьев гернгутеров, одобрил Синод православной Церкви (22.12.1763; Доклад... 1878).

Колонистам разрешалось свободное отправление веры, возможность иметь собственных священнослужителей, построение храмов (с колокольнями) за счет государства. Запрещалось организовывать монастырские общины и миссионерскую деятельность между православными (мусульман этим указом повелевалось обращать в христианство) (ПСЗ, т. 16: 313).

Российские власти придерживались принципа внутренного разобщения иноверцев, расселяли их небольшими группами, вперемежку с коренным населением. Учитывая возможность возникновения религиозных конфликтов, переселения формировали по конфессиональному принципу за редкими исключениями когда лютеране, реформаторы и католики жили вместе.

Конечно, не все обещания со стороны императрицы были выполнены. Колонистов ограничивали в общественном, экономическом и конфессиональном плане. Не оказались свободными выбор места жительства, занятия, наследия земли, передвижение вне колоний. Паспорты для перемещения как по стране, так и по региону получали те, кто рассчитался с государственными долгами. Иначе, колонисты получали временные документы, чтобы, например, осуществить торговые операции.

До 1819 г. протестанты не имели единого руководства. В теории они должны были находиться под непосредственной властью царицы, на практике - административным органом надзора стала Канцелярия опекунства иностранных переселенцев в Санкт-Петербурге, a c 28.04.1766 г. ее исполнительным органом стала Саратовская контора (за исключением гернгутерской ${ }^{17}$ колонии Сарепта, напрямую подчиненной Канцелярии с 27.03.1767 г.). В 1768 г. появились окружные комиссары, назначаемые Петербургом как промежуточное звено между иностранцами и Конторой, сводя до минимума внутреннее самоуправление колоний (ПС3, т. 17: 669). В день 20 апреля 1782 г. в ходе административной реформы империи упразднено Канцелярию и Контору, передав колонистов в ведомство губернских властей (ПСЗ,

\footnotetext{
${ }^{17}$ Пол. bracia morawscy, herrnhuci.
} 
т. 21: 491-492). Предусмотрена была даже возможность получить индивидуальные, особые привилегии. Социальный их статус не менялся - колонисты остались свободными людьми, а манифест с 1762 г. стал главым документом, регулирующим жизнь колоний.

В религиозных делах (Высочайшая... 1995) протестанты и католики подчинялись ЮЛЭФ, согласно Регламенту римско-католической изеркви в Петербурге ${ }^{18}$. Пасторы в светском отношении были поставлены в зависимость Канцелярии, а в церковных и бракоразводных делах $^{19}$ - ЮЛЭФ, где делами протестантов заведовало Петербургское консисториальное заседание.

Языком российского протестантизма стал немецкий, официальный тоже в колониях. Свободу его употребления не ограничали (Генералова 2014: 68-69), заботясь в основом об общественном порядке, чтобы в случае каких-либо правонарушений иностранцы не могли оправдываться непониманием местного наречья.

Сын и наследник Екатерины II, Павел I, впервые официально провозгласил российского императора головой Церкви, отдавая в его руки власть светскую и духовную над подданными всех вероисповеданий. В рамках теократической концепции императора был реализован план соединения восточного и западного христианства под царским руководством, при сохранении значительной степени самостоятельности различных христианских течений (Григорьев 2004). В процессе уравнивания прав религиозных групп, дополнительные привилегии получили меннониты (6.09.1800), напр., освобождение от военной и гражданской службы на все времена, освобождение от присяги перед судом, а также свободу ремесел.

Все иностранные колонии России стали подвластными нового сенатского подразделения: Экспедиции государственного хозяйства, опекунства иностранных и сельского домоводства (4.03.1797-18.07.1803) ${ }^{20}$. Перемены являлись частью большого проекта реформ государства, связанных особенно с улучшением земледельческого сословия при помощи образованных переселенцев. Поскольку царь намеревался вызвать

\footnotetext{
${ }^{18}$ Указ О сочинении Регламента был принят в ноябре 1766 г. С февраля 1769 г. его действе распространялось на протестантов.

${ }^{19}$ Браки сключались с разрешения Канцелярии.

${ }^{20} \mathrm{C} 1.07 .1833$ г. она называлась Конторой иностранных поселенцев.
} 
новых колонистов, восстановил и Саратовскую контору опекунства, подлежащую Экспедиции (1797-1802). Функционирование южных поселений регулировала Инструкция внутреннего распорядка и управления... от 17.09.1800 г. (ПСЗ, т. 26: 299-313), согласно которой колонисты подчинялись лютеранскому церковному закону и за свой счет держали священнослужителей. Из Инструкиии... видно, что на религию смотрели с государственной точки зрения, что она была средством надзора и контроля. Пасторы выполняли функции государственных чиновников, неся ответственность перед властью за народ. Для управления меннонитами и другими колонистами Новороссийского края (губернии: Екатеринославская, Херсонская, Таврическая) была создана подчиненная Экспедиции Контора опекунства новороссийских иностранных поселенцев $(26.07 .1800)^{21}$. Она также получила свою инструкцию, но без религиозных требований.

В обычном понимании планы царя считаются „мечтательством”, но Григорьев, автор монографии на эту тему, оценивает их как политику стабилизации, сближающую положение различных Церквей империи, до известной степени решающую проблему ее многоконфессиональности и способствующую снижению межконфессиональной напряженности (Григорьев 2004: 19).

Со смертью Павла I закончились его величественные проекты. Александр I продолжал только наем западных специалистов в области сельского хозяйства - образцовых землепашцев, (некоторых) ремесленников, скотоводов, садоводов (20.02.1804; ПС3, т. 18: 137-140). Протестантские колонии появились в Средней Азии, Казахстане, Кавказе, Крыму, Сибири, южной и западной Украине и в других местах (Кречмар, Ратке 1996). Численность протестантов возросла также с включением в состав империи Польши и Финляндии (1809). Отдельно к колонистам выписаны были священники (23.03.1810), отказывавшиеся от приезда из-за скудости предоставляемых им жизненных средств. На путевые издержки желающие переселиться получали кормовые деньги (пасторы немного больше ксендзов); основное жалование духовенства не повышалось (ПСЗ, т. 31: 101, 134).

${ }^{21}$ Преобразована в Попечительный Комитет о колонистах Южного Края России с тремя отделениями: Екатеринославским, Одесским и Бессарабским (1818-1876 г.). 
Проведена была реорганизация юридической структуры иноверных приходов, которая включала их в систему центрального управления государством, связанную с учреждением министерств (см. Приходько 2012), а также осуществлена была попытка унифицирования столь неодинаковых областей жизни как администрация, религия, просвещение и воспитание. Саратовскую контору (1802-1837) подчинили Департаменту государственного хозяйства и публичных зданий Министерства внутренних дел, в ведомстве которого был надзор за поощрением земледелия и промышленности (потом вошла под управление Министерства государственных имуществ, 1838-1877). ЮЛЭФ приказали поступать согласно общерусскому праву (23.12.1804; ПС3, т. 28: 759). Император утверждал устав и богослужение лютеранской церкви, стандартизовал церковный закон протестантов империи - по шведскому уставу 1686 г. (1805 г.).

В завершающем периоде министерской реформы (1810-1811) 25 июля 1810 г. все предметы инославого клира, находившиеся ранее в ведении Министерства юстиции, Римско-католической духовной коллегии и Юстиц-коллегии ${ }^{22}$ (за исключением судебных, состоявших в ведении Сената) передано организованному тогда Главному управлению духовных дел разных - с 17.08.2010 иностранных - исповеданий (далее: ГУДДИИ; ПС3, т. 31: 280). Глава ГУДДИИ сосредоточила в своих руках управление всеми религиозными конфессиями Российской империи.

В 1817 г. император дал ход новому проекту по объединению христианских Церквей. Факт этот можно связать с библейскими и мистическими увлечениями Александра I особенно после наполеонской победы (Вишленкова 1997)23. 24 октября ГУДДИИ было объединено с Министерством народного просвещения и образовано Министерство духовных дел и народного просвещения (далее: МДДиНП). Указом от 7 января 1818 г. все протестанты группировались в единую Евангелическую церковь (с апостольской преемственностью от Цер-

${ }^{22}$ Раньше (1803 г.) в рамках ЮЛЭФ установлено пост генерал-суперинтендента петербургской губерни по примеру лифляндской для смотрения за церковным порядком и ежегодных визитаций приходов (ПС3, т. 27: 431-433; т. 28: 556-560).

${ }^{23}$ Современно оцениваемый как ,экуменическая утопия”. 
кви Швеции $)^{24}$. Для управления ей учреждена была Государственная евангелическая генеральная консистория (20.06.1819), возглавляемая светским президентом. Духовным руководителем был епископ, кандидатуру которого утверждал император. Епископское управление вызвало протесты консисторий, северного дворянства, кальвинов, ввести его в действие не удалось. Епископ, назначенный в 1819 г. епископом всех протестантских церквей, в течение года был снят.

После разделения МДДиНП (15.05.1824) управление делами иностранных исповеданий снова стало самостоятельным ведомством. 20 января 1825 образована была канцелярия министра народного просвещения, которая одновременно являлась канцелярией главноуправляющего духовными делами иностранных исповеданий. При Николае I 24 августа 1827 г. был утвержден штат Департамента ГУдДИИ (ПС3-2, т. 2: 726). 25 апреля 1828 произошло разделение Министерства народного просвещения и ГУдДИИ. 2 февраля 1832 ГУДдИИ присоединили к Министерству внутренних дел в виде департамента (ПС3-2, т. 7: 53).

Политика веротерпимости, как составная имперской идеи, не касалась смены экономических условий, предлагаемых иноверным. И так в 1817 г. из-за „хорошего состояния” власти повысили меннонитам долговые суммы дла государства, а первых новороссийских колонистов сравнили в правах с казенными крестьянами (ПСЗ, т. 34: 879-881).

Административную систему протестантства закрепил Устав Евангелическо-Лютеранской иеекви... (далее: ЛЦ) от 28.12.1832 (ПС3-2, т. 7: 956-1022). Органом управления стала Евангелическолютеранская генеральная консистория (далее: ГК) с функциями упразднённой ЮЛЭФ. По делам распорядительным ГК подчинялась Министерству внутренних дел, по судным - сенату. Над ГК поставили генеральный синод (не созывался до 1924 г.). При ГК учреждена была должность прокурора, определяемого сенатом.

Закавказскими колониями руководил Колонистский синод и оберпастор, подчинявшиеся кавказскому начальству (СЗРИ: 164-168).

${ }^{24}$ В Царстве Польском действовала Евангелическо-аугсбургская церковь с аугсбургской вероисповедной формулой. Подчинялась непосредственно департаменту духовных дел иностранных исповеданий Министерства внутренних дел (Дневник 1849). 
Гернгутеров поддали консисториальному строю. Меннониты и шотландские колонисты в Каррасе (Северный Кавказ) получили свои уставы. На базельское миссионерское общество, появившееся в России по царской воле в 1819 г., наложен был запрет миссионерства; ему поручили заниматься земледелием (СЗРИ: 168-171). Уставы Николая увеличили персональные привилегии - свобода от телесных наказаний распространялась на семьи священников (15.08.1845), а их дети сравнялись в правах с детьми боярскими (СЗРИ: 67).

Юридически ЛЦ стала государственной - по образцу православной - с царем как самым высшим блюстителем ее. Император назначал или апробировал кандидатов на консисториальные посты, наблюдал за порядком во внутренних делах, на его усмотрение представлялись постановления генерального синода, им утверждались приговоры, касающиеся пасторов и отступлений от учения. Пасторы и чины консистории приносили царю присягу на верность. Правительство империи регулировало лютеранское богослужение и проповедь.

В 40-х гг. XIX в. к „немцам” применена была политика государственной интеграции; пасторы должни были иметь русское подданство, говорить по-русски (1842 г.), на русском языке проводить некоторые ритуалы (1852 г.), с 1863 г. также богослужения и библейские часы. Серьезное воздействие на положение протестантов оказало образование Германской империи. Колонисты потеряли привилегии (4.07.1871) и социальный статус, перешли под общее российское управление. Началась „руссификация”, делопроизводство переводилось на русский язык, обязательной стала русская школа. В 1874 г. на протестантов (кроме меннонитов) распространилась воинская повинность. Началась эмиграция.

Узаконенным гонениям Российская империя подвергла баптистов-штундистов (с 1880 г.). Причиной были успешные результаты их миссионерской деятельности между православными, пропаганда „социалистических идеалов”, „нарушение общественного порядка”, угроза для единства государства и господствующей Церкви. Закон от 1883 г. за проповедничество предусматривал уголовное преследование. Циркуляром от 3 сентября 1894 г., признавая штундистов „особо вредной” сектой, запрещались их молитвенные собрания (История евангельских... 1989: 97-98, 114-115). По инициативе обер-прокурора 
Синода Победоносцева меры против штунды предпринимали епископские соборы и миссионерские съезды ${ }^{25}$. Гонения прекратил только указ о веротерпимости от 17 апреля 1905 г.

Ситуация протестантизма конца XIX в. приобретает неоднозначную оценку исследователей - для одних является „полной свободой вероисповедания и богослужения” (напр. Андрощук 2012), для других - обозначает ее конец, вызвавший многочисленную эмиграцию инославных из России. Приходится согласиться с редакторами книги об истории баптизма, что в царской России „одна рука представляла свободу, а другая лишала ее” (История евангельских... 1989: 98).

История русского протестантизма в целом тесно связана с историей русского государства, его экономическими и политическими интересами, а также личными убеждениями властей или отдельных чиновников. Много уже сделано для ее выяснения, но многие вопросы ждут еще внимания и/или преодоления стереотипного мышления о них.

\section{Литература}

Андрощук В.В., 2012, Правовая регламентаиия деятельности религиозных конфессий в Российской империи (XVI - вторая половина ХIX вв.), „Журнал научных публикаций аспирантов и докторантов” № 12, с. 35-41.

Барсов Н.И., 1993, Протестантизм в России, в: Христианство. Энщиклопедический словарь, Москва, с. 406-411, <www.tvoyhram.ru/protestantizm/protestant06. $\mathrm{html}>, 1.09 .2015$.

Вишленкова Е.А., 1997, Религиозная политика: офищиальный курс и „общее мнение” России Александровской эпохи, Казань.

Генералова Н.П., 2014, Религиозная жизнь как фактор сохранения начиональной идентичности и родного языка первых поволжских немцев-колонистов, „Science Time” № 9 (9), c. 67-71.

Григорьев С.Л., 2004, Религиозные взгляды и религиозная политика Павла I, Екатеринбург. Автореф. дисс. на соискание уч. степ. к. и. н.

Доброклонский А.П., 2001, Руководство по истории Русской Церкви, Москва.

История евангельских христиан-баптистов в СССР, 1989, Ленинград.

История российских немиев в документах (1763-1992 г2.), 1993, сост. В.А. Ауман, В.Г. Чеботарева, Москва.

\footnotetext{
${ }^{25}$ Роль съездов в религиозной политике России будет темой отдельной статьи.
} 
Кречмар Г., Ратке Г., 1996, Евангелическо-Лютеранская Церковь в России, на Украине, в Казахстане и Средней Азии (ЕЛЦ), Санкт-Петербург.

Курило О.В., 2002, Лютеране в России XVI-XX вв., Москва.

Ларионов А.Э., 2006, Взаимоотношения православия и протестантизма в XVI в. в освещении русской иерковной историографии, в: Мир культуры: История и современность, Москва, с. 48-53.

Марчалис Н., 2009, Люторь иже лютъ, Москва.

Миненко С.В., 2011а, Российское законодательство по охране господствующей православной веры от прозелитизма иноверческих иерквей (XVIII-XIX века), „Юридическая наука и практика” № 1, с. 46-50.

Миненко С.В., 2011б, Правовое положение римско-католической и евангелическо-лютеранской иерквей в России XVI-первой половины XIX вв. (историкоправовой аспект), Автореф. дисс. на соискание уч. степ. к. ю. н.

Приходько М.А., 2012, Управление делами иностранных исповеданий и государственная система в России в 1-й трети XIX в. (Историко-правовой аспект), „Lex Russica” № 4, c. 706-724.

Ревуненкова Н., 2007, Протестантизм, Москва-Санкт-Петербург.

Терюкова Е.А., 2010, Департамент Духовных дел иностранных исповеданий и этноконфессиональная политика Российского государства (XVIII - начало $X X$ в.), „Государство, религия, церковь в России и за рубежом” № 4, c. 204-208.

Цветаев Д., 1883, Положение протестантов в России до Петра Великого, „Журнал Министерства Народнаго Просвещения” № 9, с. 66-207.

Цветаев Д., 1890, Протестантизм и протестанты в России до эпохи преобразований. Историческое исследование, Москва.

\section{Источники}

Fechner A.V., 1876, Chronik der evangelischen Gemeinde in Moskau..., Bd. I, Moskau.

Буссов К., 1998, Московская хроника, 1584-1613, в: Хроники Смутного времени, Москва, с. 11-158.

Высочайшая грамота, данная императрицей Екатериной II колонистам Capenmbl, 1995, Сарепта, Саратов, с. 67-76, <http://geschichte.rusdeutsch.ru $/$ hist $=1 \&$ hmenu $0=2 \&$ hmenu01 $=9 \&$ hmenu02 $=54>, 21.09 .2015$.

Горсей Д., 1991, Записки о России XVI - начало XVII, Москва. Дневник законов, 1849, т. 42, Варшава.

Доклад синода о дозволении братьям гернгутерам селиться в России, 22 декабря 1763 г., 1878, „Русская старина” т. 23, № 12, с. 712-713.

Маржерет Ж., 1982, Россия начала XVII в. Записки капитана Маржерета, сост. Ю.А. Лимонов, ред. В.И. Буганов, перев. Т.И. Шаскольская, Н.В. Ревуненков, Москва. 
Миллер Ф., 1788, Известие историческое о Антоние Поссевине.., в: Н. Новиков, Древняя российская вивлиофика, ч. 6, Москва, с. 71-107.

Миненко С.В., 2008, Осоденности вероисповедной политики в российском государстве и отношение власти к инославным конфессиям в: Проблемы юридического образования. Материаль VI Межрегиональной научной конферениии 21 апреля 2008 года-Москва, Нижний Новгород 2008, с. 122-126.

„Москва евангельская”. Каталог-справочник ичерквей и христианских организаций Москвы и Московской области, 2012, Санкт-Петербург.

Одерборн П., 1585, Жизнь Иоанна Васильевича, великого князя Московии (Paullus Oderbornius, 1585, Ioannis Basilidis Magni Moscoviae Ducis Vita, Виттенберг).

Олеарий А., 2003, Описание путешествия в Московию, Москва.

Полное собрание законов Российской империи, собр. 1 (далее: ПСЗ) СПб., 1830, т. $6,9,16,17,18,21,26,27,28,31,34$.

Полное собрание законов Российской империи, собр. 2 (далее: ПС3-2), СПб., т. 2 (1830), 7 (1833).

Послание царя Алексея Михайловича Святителю Мученику Филиппу, 2005, в: Российское самодержавие первых Романовых, сост., предисл., комм. Г.В. Талиной, ред. С.В. Перевезенцев, Москва, с. 160-162.

Свод законов Российской империи (далее: СЗРИ), 1857, т. 11, ч. 1: Уставь духовных дел иностранных исповеданий, Санкт-Петербург.

Указная книга земского приказа, 1889, в: Хрестоматия по истории русского права, сост. М. Владимирский-Буданов, изд. 3, Киев-Санкт-Петербург. 